\title{
Editors' Introduction: Empirical Evidence on the Relevance of Place in Criminology
}

\author{
Anthony A. Braga · David L. Weisburd
}

Published online: 18 December 2009

(C) Springer Science+Business Media, LLC 2009

For most of the last century criminologists have focused their understanding of crime on individuals and communities (Nettler 1978; Sherman 1995; Weisburd et al. 2009). In the case of individuals, criminologists have sought to understand why certain people as opposed to others become criminals (e.g. see Akers 1973; Gottfredson and Hirschi 1990; Hirschi 1969; Raine 1993), or to explain why certain offenders become involved in criminal activity at different stages of the life course or cease involvement at other stages (e.g., see Moffitt 1993; Sampson and Laub 1993). In the case of communities, criminologists have often tried to explain why certain types of crime or different levels of criminality are found in some communities as contrasted with others (e.g., see Agnew 1999; Bursik and Grasmick 1993; Sampson and Groves 1989; Shaw and McKay 1942) or how community-level variables, such as relative deprivation, low socioeconomic status, or lack of economic opportunity may affect individual criminality (e.g. see Agnew 1992; Cloward and Ohlin 1960; Merton 1938; Wolfgang and Ferracuti 1967). In most cases, research on communities has focused on the "macro" level, often studying states (Loftin and Hill 1974), cities (Baumer et al. 1998), and neighborhoods (Sampson 1985; Bursik and Grasmick 1993).

While concern with the relationship between crime and place goes back to the founding generations of modern criminology (Guerry 1833; Quetelet 1842), the "micro" approach to places emerged only in the last few decades (e.g. see Brantingham and Brantingham

This introductory essay draws upon material presented in Braga and Weisburd (2010).

A. A. Braga (ه)

Harvard University, Cambridge, MA, USA

e-mail: Anthony_Braga@harvard.edu

\author{
A. A. Braga \\ University of California, Berkeley, CA, USA \\ D. L. Weisburd \\ Hebrew University, Jerusalem, Israel \\ D. L. Weisburd \\ George Mason University, Fairfax, VA, USA
}


1975, 1981; Duffala 1976; LeBeau 1987; Mayhew et al. 1976; Rengert 1980, 1981). ${ }^{1}$ Places in this "micro" context are specific locations within the larger social environments of communities and neighborhoods (Eck and Weisburd 1995). They are sometimes defined as buildings or addresses (see Green 1996; Sherman et al. 1989), sometimes as block faces or street segments (see Sherman and Weisburd 1995; Taylor 1997), and sometimes as clusters of addresses, block faces or street segments (see Block et al. 1995; Weisburd and Green 1995; Weisburd et al. 2009).

In the mid to late 1980s a group of criminologists began to examine the distribution of crime at micro places. Their findings were to radically alter the way many criminologists understood the crime equation, drawing them into a new area of inquiry that was to have important implications for police practice. Perhaps the most influential of these studies was conducted by Lawrence Sherman and his colleagues (Sherman et al. 1989). Looking at crime addresses in the city of Minneapolis they found a concentration of crime at place that was startling. Only 5\% percent of the addresses in Minneapolis accounted for $50 \%$ of the crime calls to the police. Similar results were reported in a series of other studies in different locations and using different methodologies, each suggesting a very high concentration of crime in micro places (e.g. see Pierce et al. 1988; Eck et al. 2000; Weisburd et al. 1992; Weisburd and Green 1994).

Importantly, such concentration of crime at discrete places does not necessarily follow traditional ideas about crime and communities. There were often discrete places free of crime in neighborhoods that were considered troubled, and crime hot spots in neighborhoods that were seen generally as advantaged and not crime prone (Weisburd and Green 1994). This empirical research thus reinforced theoretical perspectives that emphasized the importance of crime places, and suggested a focus upon small areas, often encompassing only one or a few city blocks that could be defined as "hot spots" of crime.

In the early years of this new century, a research team from the University of Maryland was able to gain a long series of data on crime from the Seattle Police Department (Weisburd et al. 2004). These data not only reinforced the early findings in Minneapolis, they illustrated that crime hot spots have a surprising degree of stability of offending rates over time. Looking at crime incidents at street segments in Seattle over a 14-year period, they found that year to year about $50 \%$ of the crime was found in approximately $5 \%$ of street segments. This finding is remarkable not only because it is so close to those reported in the Minneapolis study (Sherman et al. 1989) but also because it now established the stability of such crime concentrations year to year.

Of course, the concentration of crime year to year, does not preclude the possibility that each year different crime hot spots would develop, or that hot spots in one year would naturally become cool the next. Such "regression to the mean" is common in social phenomena, and a key concern for the idea of place-oriented crime prevention was that the same places would evidence high crime activity year to year. Only very strong continuity in crime hot spots would support a large scale commitment to hot spots as a focus of prevention policy and practice.

For this reason, the Seattle study also looked at the developmental trends of street segments in Seattle over the 14-year period studied. Using a recently developed technique for identifying crime trends over time (see Nagin 1999), the approximately 30,000 street segments in Seattle were grouped into "trajectories" with similar developmental trends

\footnotetext{
${ }^{1}$ It should be noted that a few early criminologists did examine the "micro" idea of place as discussed here (see Shaw and Myers, 1929). However, interest in micro places was not sustained and did not lead to significant theoretical or empirical inquiry.
} 
over time. Weisburd et al. (2004) identified a group of high crime street segments that represented only about one percent of the street segments in Seattle and consistently accounted for a very large share of reported crime between 1989 and 2002. While there were developmental trends with some trajectory groups increasing or decreasing, hot spots of crime evidence a remarkable degree of stability, at least over the time period examined in the Seattle study. This is true not only for the hot spots, but also for the vast majority of places in the city that show very low and stable crime rates over time.

Despite a growing theoretical and scientific base, gaps remain in our knowledge of crime and place. Moreover, crime prevention theory and practice often continue to ignore the importance of place. This special issue of the Journal of Quantitative Criminology is devoted to advancing the empirical study of crime at micro places. The six papers published in this peer-reviewed volume were presented at a special symposium on "Empirical Evidence on the Relevance of Place in Criminology" sponsored by the Crime and Place Working Group, a research program of the Center for Evidence-Based Crime Policy at George Mason University (April 22, 2009). ${ }^{2}$ These papers use state-of the art statistical models, such as group-based trajectory analyses and discrete choice modeling, to examine timely and important issues such as the stability of crime at places over time and the relevance of specific place characteristics and dynamics to the clustering of criminal events.

Groff, Weisburd, and Yang expand upon the influential Weisburd et al. (2004) longitudinal study that revealed crime concentrations across micro places were relatively stable over time in Seattle, Washington. The original study did not examine the degree of block to block variability in crime at the local micro level. Groff et al. answer this question by using trajectory analysis and quantitative spatial statistics to examine both temporal and spatial variation in crime across street blocks in Seattle over a 16-year time period. The authors find a surprising number of cases where individual street segments have trajectories which are unrelated to their immediately adjacent streets. This heterogeneity suggests it may be particularly important to examine crime trends at very local geographic levels. Groff et al. suggest that these findings reinforce the importance of place-oriented crime prevention strategies, such as "hot spots policing," which address specific streets within relatively small areas.

Braga, Papachristos, and Hureau examine the role of micro places in understanding the sudden epidemic of gun violence during the late 1980s and early 1990s and the subsequent, unexpected large downturn in gun violence in the mid 1990s. The authors use growth curve regression models to uncover distinctive developmental trends in gun assault incidents at street segments and intersections in Boston, Massachusetts from 1980 through 2008. Braga et al. find that only $5 \%$ of street segments and intersections in Boston generated $74 \%$ of shootings over this time period and the same hot spot micro places experienced nearly all of the upswings and downturns in Boston gun violence over the 29-year study time period. These results suggest that the urban gun violence epidemic, and sudden downturn in urban gun violence in the late 1990s, may be best understood by examining highly volatile microlevel trends at a relatively small number of places in urban environments.

Using Situational Action Theory, Wikström, Ceccato, Hardie, and Treiber use data from the Peterborough Adolescent and Young Adult Development Study (UK) to study the role of the social environment, particularly the person and place interaction, in crime causation.

\footnotetext{
2 The core members of the Crime and Place Working group are David Weisburd, Elizabeth Groff, Brian Lawton, Anthony Braga, Gerben Bruinsma, James Bueermann, John Eck, Cynthia Lum, Jerry Ratcliffe, George Rengert, Nigel Waters, and Sue-Ming Yang. See http:/gunston.gmu.edu/cebcp/cpwg.html.
} 
The authors introduce and examine the usefulness of the "space-time budget" methodology as a means of capturing people's exposure to settings and describing their activity fields. Wikström et al. find noteworthy associations between young people's activity fields and their exposure to criminogenic settings, young people's their exposure to criminogenic settings and their crime involvement, and, most importantly, that the influence of criminogenic exposure depends on a person's crime propensity. The authors conclude that having a crime-averse morality and strong ability to exercise self-control appears to make young people practically situationally immune to the influences of criminogenic settings, while having a crime-prone morality and poor ability to exercise self-control appears to make young people situationally vulnerable to the influences of criminogenic settings in small places.

Johnson and Bowers analyze the role of the permeability of specific street networks on the location of crime in one police district in Merseyside (UK). The authors analyze burglary at the street segment level and use Hierarchical Linear Models to account for the multi-level structure of the data and to examine the effect of permeability on burglary in a large study area where there is considerable variation in street network configuration. Johnson and Bowers find that increased permeability is associated with elevated burglary risk, that burglary risk is lower on cul-de-sacs (particularly those that are sinuous in nature), and that the risk of burglary is higher on more major roads and those street segments that are connected to them. Using a discrete choice analytic framework that includes the spatial competition model, Bernasco analyzes burglary location choice data from the Netherlands at detailed spatial resolutions: the average unit of analysis is an area of only 18 residential units and 40 residents. While the use of very small geographic units is well justified in the literature on discrete choice models and the spatial choice made by burglars, Bernasco's analysis suggests that small spatial units depend strongly on their environment and, as such, discrete choice models need to take into account spatial interdependence when modeling the decisions made by burglars in choosing specific crime locations.

In our final paper, Yang examines the spatial-temporal relationship between disorder and violence at the census block group level. While some criminologists and policy analysts suggest that disorder and violent crime are highly correlated in neighborhoods over time, very few scholars have examined the relationship between violent crime and disorder at micro places within neighborhoods and tried to assess the strength of the purported relationship over longer periods of time. Yang uses Group-based Trajectory Analysis and Joint Trajectory Analysis to explore the longitudinal relationship between disorder and violence in Seattle over a 16-year time period. Her analyses reveal that, like violent crime, disorder is concentrated in a relatively small number of hot spot areas in the city. However, while disorder and violent crime is found to be correlated in these relatively small areas over time, the relationship is not perfect with some high-disorder places experiencing low levels of violence over time. Given the prominence of dealing with disorderly conditions in crime prevention theory and practice, Yang suggests that additional theoretical and empirical work is necessary to better understand the cross-sectional and longitudinal relationship between violence and disorderly conditions at places.

While the larger worlds of communities and neighborhood have been the primary focus of crime prevention theory and research in the past, there is a growing recognition of the importance of shifting that focus to the small worlds in which the attributes of place and its routine activities combine to develop crime events (Eck and Weisburd 1995). As the empirical evidence reviewed in this special issue confirms, crime is highly concentrated in a small number of hot spot places that are generally stable targets for intervention over 
time. According to Harvard sociologist Robert Sampson, the idea of crime hot spots suggests a crime prevention response that in the end may be more effective than policies that simply target individuals or families (Sampson 2002, p. 243). By proactively responding to neighborhoods and places that disproportionately generate crimes, Sampson suggests that proactive place-based strategies can more effectively stave off crime epidemics and their spatial diffusion when compared to crime prevention strategies that target people. We agree with his assessment and believe it is time for criminologists, policy makers, and practitioners to focus on very small units of analysis when trying to understand and address crime problems.

\section{References}

Agnew R (1992) Foundation for a general strain theory of crime and delinquency. Criminology 30:47-84 Agnew R (1999) A general strain theory of community differences in crime rates. J Res Crime Delinq 36:123-155

Akers R (1973) Deviant behavior: a social learning approach. Wadsworth, Belmont, CA

Baumer E, Lauritsen J, Rosenfeld R, Wright R (1998) The influence of crack cocaine on robbery, burglary, and homicide rates: a cross-city, longitudinal analysis. J Res Crime Delinq 35:316-340

Block CR, Dabdoub M, Fregly S (eds) (1995) Crime analysis through computer mapping. Police Executive Research Forum, Washington, DC

Braga AA, Weisburd DL (2010) Policing problem places: crime hot spots and effective prevention. Oxford University Press, New York

Brantingham PJ, Brantingham PL (1975) Residential burglary and urban form. Urb Stud 12:273-284

Brantingham PJ, Brantingham PL (1981) Notes on the geometry of crime. In: Brantingham PJ, Brantingham PL (eds) Environmental criminology. Sage Publications, Beverly Hills, pp 27-54

Bursik R, Grasmick H (1993) Neighborhoods and crime: the dimensions of effective community control. Lexington Books, Lexington

Cloward R, Ohlin L (1960) Delinquency and opportunity. Free Press, Glencoe

Duffala DC (1976) Convenience stores, robbery, and physical environmental features. Am Behav Sci 20:227-246

Eck JE, Weisburd D (1995) Crime places in crime theory. In: Eck JE, Weisburd D (eds) Crime and place, crime prevention studies, vol 4. Criminal Justice Press, Monsey, pp 1-33

Eck JE, Gersh J, Taylor C (2000) Finding hot spots through repeat address mapping. In: Goldsmith V, McGuire P, Mollenkopf J, Ross T (eds) Analyzing crime patterns: frontiers of practice. Sage Publications, Thousand Oaks, pp 49-64

Gottfredson M, Hirschi T (1990) A general theory of crime. Stanford University Press, Stanford

Green L (1996) Policing places with drug problems. Sage Publications, Thousand Oaks

Guerry AM (1833) Essai sur la Statistique Morale de la France. Crochard, Paris

Hirschi T (1969) Causes of delinquency. University of California Press, Berkeley

LeBeau J (1987) The methods and measures of centrography and the spatial dynamics of rape. J Quant Criminol 3:125-141

Loftin C, Hill R (1974) Regional subculture and homicide: an examination of the Gastil-Hackney thesis. Am Sociol Rev 39:714-724

Mayhew P, Clarke RV, Sturman A, Hough M (1976) Crime as opportunity, home office research study 34, H.M. Stationary Office, London

Merton RK (1938) Social structure and anomie. Am Sociol Rev 3:672-682

Moffitt T (1993) Adolescence-limited and life-course persistent antisocial behavior: a developmental taxonomy. Psych Rev 4:674-701

Nagin D (1999) Analyzing developmental trajectories: a semiparametric, group-based approach. Psych Methods 4:139-157

Nettler G (1978) Explaining crime, 2nd edn. McGraw Hill, New York

Pierce GL, Spaar S, Briggs L (1988) The character of police work strategic and tactical implications. Center for Applied Social Research, Boston

Quetelet AJ (1842) A treatise of man, scholar's facsimiles and reprints (1969 ed). Gainesville, FL

Raine A (1993) The psychopathy of crime. Academic Press, New York 
Rengert G (1980) Theory and practice in urban police response. In: Georges-Abeyie D, Harries K (eds) Crime: a spatial perspective. Columbia University Press, New York, pp 276-289

Rengert G (1981) Burglary in Philadelphia: A critique of an opportunity structure model. In: Brantingham PJ, Brantingham PL (eds) Environmental criminology. Sage Publications, Beverly Hills, pp 189-201

Sampson R (1985) Neighborhood and crime: the structural determinants of personal victimization. J Res Crime Delinq 22:7-40

Sampson R (2002) The community. In: Wilson JQ, Petersilia J (eds) Crime, 2nd edn. ICS Press, Oakland, pp $193-216$

Sampson R, Groves WB (1989) Community structure and crime: testing social disorganization theory. Am J Sociol 94:774-802

Sampson R, Laub J (1993) Crime in the making: pathways and turning points through life. Harvard University Press, Cambridge

Shaw C, McKay H (1942) Juvenile delinquency in Urban areas. University of Chicago Press, Chicago

Shaw C, Myers E (1929) The juvenile delinquent. Illinois Crime Survey, Illinois Association for Criminal Justice, Chicago

Sherman L (1995) Hot spots of crime and criminal careers of places. In: Eck J, Weisburd DL (eds) Crime and place, crime prevention studies, vol 4. Criminal Justice Press, Monsey, pp 35-65

Sherman L, Weisburd D (1995) General deterrent effects of police patrol in crime hot spots: a randomized controlled trial. Just Q 12:625-648

Sherman L, Gartin P, Buerger M (1989) Hot spots of predatory crime: routine activities and the criminology of place. Criminology 27:27-56

Taylor R (1997) Social order and disorder of street-blocks and neighborhoods: ecology, micro-ecology, and the systematic model of social disorganization. J Res Crime Delinq 34:113-155

Weisburd DL, Green (Mazerolle) L (1994) Defining the street-level drug market. In: MacKenzie DL, Uchida CD (eds) Drugs and crime: evaluating public policy initiatives. Sage Publications, Thousand Oaks, pp 61-76

Weisburd DL, Green (Mazerolle) L (1995) Policing drug hot spots: the Jersey City DMA experiment. Just Q 12:711-736

Weisburd DL, Maher L, Sherman L (1992) Contrasting crime general and crime specific theory: the case of hot spots of crime. Adv Criminol Theory 4:45-69

Weisburd DL, Bushway S, Lum C, Yang S-M (2004) Trajectories of crime at places: a longitudinal study of street segments in the city of Seattle. Criminology 42:283-321

Weisburd DL, Bernasco W, Bruinsma G (eds) (2009) Putting crime in its place: units of analysis in geographic criminology. Springer, New York

Wolfgang M, Ferracuti F (1967) The subculture of violence: toward an integrated theory in criminology. Tavistock, New York 